\title{
Awareness of the Recreational Tourism Sector Workers Arabic Republic of Egypt "Evaluative Study"
}

\author{
Mohamed Omar Abdulrasoul Abdullah ${ }^{1}$ \\ ${ }^{1}$ Lecturer at the Sports Recreation Department, Faculty of Physical Education for Girls, Alexandria University, Egypt
}

\begin{abstract}
:
Research aims to assess awareness of the recreational tourism sector workers Arabic Republic of Egypt, use descriptive researcher and sample size (200) staff working in tourism, Arabic Republic of Egypt

The most important results proved that the level of awareness results in recreational tourism sector of the Republic of Egypt Arabic average percentage ranging from $57.5 \%$ to $65 \%$, there is a dearth of tourist recreation specialist within tourism professionals.
\end{abstract}

\section{The most important recommendations:}

The need to pay attention to tourism professionals for recreational awareness because of its positive impact to tourism development, providing specialized cadres in leisure tourism for tourism within the Arabic Republic of Egypt attractions, Attention to the need for cooperation between the Arabic Republic of Egypt attractions and other institutions, including departments of recreation physical education colleges to provide suitable graduates for the job market ' Recreational tourism awareness through various media in tourism sector workers Arabic Republic of Egypt.

Keywords: Awareness -Recreation-Tourism-workers - Tourism sector

\section{Introduction:}

\begin{abstract}
A wareness is an active recreational tourism promotion process in any region of the world, is an important factor in the expansion of the tourist population horizon in how to treat them with domestic or foreign tourists who come to see the tourist spots and monuments and enjoy the landscape that has the city's famous city, as well as to learn about the history of peoples by regions and archaeological and historical evidence. Today we observe frequent visitors to historic places and archaeological and religious landscape, recreational tourism of
\end{abstract}

Nature and therapeutic. As our varied tourist phenomena which can be invested toward the tourist side to be another source of the national economy, plus the need for awareness of recreational tourist system capable of recreational tourism investment as investment in tourist facilities became associated in many cases where workers recreational awareness

So it became one of the most important tourism sectors in countries where this is due to the fact that tourism income contributes to the economic social and environmental, in addition to tourism and labor sought to help tourism on cultural heritage (Ehab Mohamed Osman),

Tourism is a civilized message and intercultural communication bridge and human knowledge among Nations and peoples and is result from the evolution of societies and high standard of living for the individual and the exploitation of leisure and a source of national income and improving the balance of payments through the flow of foreign currencies, where reputed tourism industry in recent important changes where described as economic giant of the 20th century, industry first and third service industry's export economy in the current century hope (Mohamed Omar Abdul Rassul, 2015)

And awareness of important recreational and factor in tourism and its development on the one hand and the tourist and influence the psychology of the other, so that most of the States that possess tourist movement and structural action programs are in the treatment of national and foreign tourists for the tourist who is visiting a tourist area or a particular country conveys his image and aspirations and its watchers and treating people to parent society members if the image conveyed by good and 
decent treatment for his people will encourage others to delegations to the region or country you visited by tourist and vice versa if The picture opposite, this affects come to that State or city, (Ahmed Fadil, 2002)

Cultural and media terms, domestic tourism important for citizens to know the contours of his homeland and the development and upgrading of cultural awareness and raise consciousness reflected good recreational its understanding with foreign tourists and preserve archaeological and tourist facilities and facilities for foreign tourists and treated well, will be reflected in the transfer of information about the country that he has visited to people which creates a free country and city information (Sabah Mahmoud Mohamed et al, 2007 )

So the awareness among the population of recreational city or country in General is very important and must be seriously and bring it if tourist movement through which we get acceptable results in economic, social and cultural side. (For an educational role that tourism is constantly increasing as educational institution through which you can learn communication and consolidation of social relations and psychological human evolution through health maintenance and renewal of strength when tired.) (Arabic tourism magazine, 2010)

Then we must cultivate recreational education in the minds of the tourist sector to increase awareness of their recreational reflected in how to treat foreign and Arab tourists to achieve what is best for the continuity of arrivals at us. The consolidated humanitarian relations facts exchanged between individuals and groups. (As her tourism plays an active and important human relationships because it's a natural phenomenon stemming from the nature of man and nature and contained of instincts and senses since creation) (Mohamed Hassan Bazooka, 2008)

Here affect recreational education on tourism in the country in General and we must instill awareness of recreational tourism sector has to start with so we activated to spread awareness in the minds of the tourism sector. To have the possibility of recreational awareness when everyone to reflect on tourism (Mohamed Aldulaimi and Fawaz Al-Mousa, 2009) http://ibnsaba. com/jeeran. archive/2010/1/1009840. Htm) (Researcher finds that tourism to recreational undecideds tourist services on the Arabic Republic of Egypt tourist places, so as to achieve greater benefit to attract tourism, especially in light of the current situation and experiencing a big slump in tourism, whether at the level of the basic structure of lounges and hardware necessary for Recreation Sports or having qualified individuals who have experiences that help them provide those services separately from the others and thus achieved an important objective of the tourism.

Researcher finds that a very important tourism and recreation for leisure I have clients of tourist facilities, where existing tourist recreation must follow quality standards when providing recreational tourists on tourist places, to exercise many recreational activities offered by institutions both governmental and civil institution through which the individual acquires many experiences physical and mental health and psychological and social services in accordance with the quality standards, under existing tourists in Arabic Republic of Egypt attractions to satisfy Their needs and desires, the researcher has noted through his work in the field of tourist recreation tourism institutions spread lately especially offering services in touristic recreational undecided, but it may lead to personal and depend on the capabilities of individuals based on leisure tourism.So the view finder due to the importance of awareness of recreational tourism workers in particular. The importance and ability of these thousand percent of employees in dealing with clients, as well as the need in their requirements of this age, and respond to rapid change in employment, particularly in sector c arena, necessitating a renewed awareness of the recreational ones to create a sense of responsibility and awareness of the extent of the challenge before them, which leads to the development of awareness of the recreational tourism workers in Arab Republic of EgyptThe present and the future, understand the category best able to put things right, so it's important to recreational awareness calendar tourism professionals to work on raising awareness of recreational, then redressing recreational awareness is crucial when working in the tourism sector, more than capable of developing tourism in the Arabic Republic of Egypt

\section{Research objectives}

Research aims to

1- learn awareness of tourism to recreational tourism sector workers Arabic Republic of Egypt.

2- to understand the importance of awareness in recreational tourism sector workers Arabic Republic of Egypt

\section{Search questions:}

1- What is the recreational tourism awareness among workers in the tourism sector of the Republic of Egypt Arabic? 
2- how to understand the importance of awareness in recreational tourism sector workers Arabic Republic of Egypt?

\section{Research procedures:}

\section{Method :}

The researcher utilized the descriptive survey method because of it appropriated to the research nature

\section{The sample:}

It was selected deliberately from tourism regions in the Arab Republic of Egypt five governorates (FayoumAlgeeza-Alexandria-South Sainai (SharmElsheikh- Red Sea(Herghada), while major sample was selected randomly from workers of tourism field from those governorates $m$ it was(200)

In the field of tourism (40)workers in tourism from each province, and selected a random sample and (50) factor in tourism (10) tourism agent from each province to conduct surveys

\section{Data collection tools:}

The researcher has utilized a questionnaire as a data collection tool

Researcher access and readings of the studies conducted in this area because of the lack of an appropriate tool within science researcher for this purpose, a questionnaire design might require recreational awareness to see how the tourism sector awareness of Arabic Republic of Egypt. Researcher access and readings of the studies conducted in this area because of the lack of an appropriate tool within science researcher for this purpose, a questionnaire design might require recreational awareness to see how the tourism sector awareness of Arabic Republic of Egypt

The researcher took into account in setting out the form of the following aspects:

1- not be wording in a way that suggests certain answers

2- stay away from difficult words incomprehensible.

3- the number of suitable words for research purposes

The researcher has resulted a questionnaire related to the study to recognize the suggested recreational awareness with tourism sector employees in A.R.E to realize research aims, the statements of questionnaire of research sample was collected and included for research subthemes. In order to rationing questionnaire the researcher utilized the following scientific transactions:

Validity
Arbitrators validity

By presenting the questionnaire to experts:

The researcher utilized arbitrators validity (content validity) hens he utilized "7" experts in the sports recreation and tourism field workers .

He distributed the questionnaire on experts by interview , he explained research idea, questionnaire purpose, how he designed it for having opinions.

Experts opinions clarified that the suitable statements number of questionnaire subthemes under discussion, the total number was(20) representing final questionnaire format.

In the spot light of experts is agreement about questionnaire statements, the researcher accepted more than $80 \%$ of experts agreement on the suggested statements.

Opinions was between about (85.71\%-100\%) the researcher accepted (80\%) for statement acceptance ,so all statements were accepted.

B-Internal constancy validity:

Researcher found Internal constancy validity of questionnaire, by calculating correlation coefficient between every statement 's degree and questionnaire degree at all.

correlation coefficient is values was in between(.72),(.89\%) which proved Internal constancy validity of questionnaire under discussion

Questionnaire stability:

Researcher utilized partial fragmentation for calculating stability coefficient for carry out pilot random sample (50) individuals out of major sample with the same characteristics, stability coefficient was calculated, there was a significant statistics correlation relation between questionnaire partial fragmentations in between $(.74 \%, .89 \%)$

\section{Steps to set up the questionnaire}

The initial image is set to the form and then view the form on a group of experts to find out their opinion in the form of it:

1- Appropriateness of statements of the questionnaire to measure the target set for him.

2- modify or add what they see fit for each term of the form. 
3- appropriateness of number phrases in this form.

4- make use of expert opinions in their reviews on phraseology form

Based on the positive views of experts masters, a many appropriate adjustments and become statements of the form (20) statements and every term (3) selections and give each one the correct choice, and then put the finalized form Annex (1)

\section{The exploratory study:}

Researcher has conducted An exploratory study to verify the appropriateness of statements of the questionnaire which was designed for exploratory sample (50) workers in tourism and have the same characteristics of respondents to identify the validity \&stability.

Researcher has verified the stability of the test on a sample of 50 workers in tourism and use (re-test) where the first application questionnaire to find the correlation coefficient (Pearson) between the two applications and the correlation coefficient 0.88 , its high
The researcher has found the application validity by differentiation validity to compare terminal, there is a significant statistical differences between the up and top springs favor to the top one, which confirms the questionnaire validity under discussion.

\section{The major study:}

The application was applied in the final format on the research sample in the period of (10/7/2016-12/9/2016)

\section{The statistical transactions:}

The researcher utilized the following statistical transactions:

1- mean

2- standard deviation

3- Pearson correlation coefficient

4- T Tests

Results discussion:

Table (1)

The Mean, Standard Deviation for Recreational Awareness with tourism Field Workers in the Arab Republic of Egypt $\mathbf{N}=\mathbf{2 0 0}$

\begin{tabular}{|c|c|c|c|c|}
\hline Serial & Governorates & Mean & $\begin{array}{c}\text { Standard } \\
\text { Deviation }\end{array}$ & Percentage rate \\
\hline $1-$ & Fayoum & 11.5 & 1 & $57.5 \%$ \\
\hline $2-$ & Algeeza & 12 & 1 & $60 \%$ \\
\hline $3-$ & South Sinai (Sharm el Sheikh) & 13 & 2 & $65 \%$ \\
\hline $4-$ & Alexandria & 11.5 & 1 & $57.5 \%$ \\
\hline $5-$ & Albahrlahmar(Hurghada) & 12.5 & 1 & $62.5 \%$ \\
\hline
\end{tabular}

Table (1) shows mean \& standard deviation of recreational awareness among workers in tourism of the Republic of Egypt Arabic in five governorates in Arabic Republic of Egypt under the search results according to the following:
Tourism workers came South Sinai (Sharm el Sheikh) first with themean of 13 tourism workers came to AlbahrAlahmar (Hurghada) in second order mean reached $12.5^{\circ}$ tourism workers came to Giza in third order with mean of 12 degrees was working in tourism in Fayoum and Alexandria in fourth and fourth order repeating table 11.5 degrees reached the mean

Table (2)

Percentage Rates of the importance of awareness perception in recreational tourism sector workers Arabic Republic of Egypt $\mathrm{N}=\mathbf{2 0 0}$

\begin{tabular}{|c|c|c|c|}
\hline Serial & Governorates & Mean & Percentage Rats \\
\hline $1-$ & Fayoum & 11.5 & $57.5 \%$ \\
\hline $2-$ & Algeeza & 12 & $60 \%$ \\
\hline $3-$ & South Sinai (Sharm el Sheikh) & 13 & $65 \%$ \\
\hline $4-$ & Alexandria & 11.5 & $57.5 \%$ \\
\hline 5 & Albahrlahmar(Hurghada) & 12.5 & $62.5 \%$ \\
\hline
\end{tabular}


Table (2) shows Percentage Rates of the importance of awareness perception in recreational tourism sector workers Arabic Republic of EgyptThat results in accordance with the following:

- Tourism workers came South Sinai (Sharm el Sheikh) first by a percentage amounting to $65 \%$

- tourism workers came to the Red Sea (Hurghada) in second order percentage reached $62.5 \%$

- tourism workers came to Giza third $60 \%$ percentage came tourism *professionals in Fayoum and Alexandria in fourth and fourth order repeating a percentage amounting to $57.5 \%$

Researcher finds that the level of awareness in recreational tourism sector workers Arabic Republic of Egypt comes moderately has ranged from $57.5 \%$ to $65 \%$, due to the scarce results $t$ in tourist recreation specialist within the tourism professionals and especially graduates of departments of physical education colleges and recreation rely on personal experiences among workers in tourism, Arabic Republic of Egypt.

It might be due to the lack of awareness of leisure among workers in tourism despite the availability of Arabic Republic of Egypt places that suit the recreational activities in the governorates under discussion. The results of this study are consistent with the results of a study (Mohamed Omar Abdul Rasul, 2015) (Mohamed Omar Abdul Rasul, 2008), (Ehab Mohamed Osman, 2010, Mohamed r Abdul Hamid, 2003),((Kaiser , S.2002) ‘(F Felkel itness2001)

The Arabic Republic of Egypt attractions is an important and essential role in the development of recreational consciousness so there must be specialists in leisure tourism and appropriate programs and capabilities that help the growth of recreational awareness. The Arabic Republic of Egypt attractions that where not available specialists and recreational programs and activities do not help increase occupancy by tourist hotels

Recreational tourism is no longer just a service to an individual, these services click it right necessary for the individual should in his spare time this leisure and recreation Charter but tourist recreation lead to higher level this individual and his enlightenment and improve its quality, thereby improving the investment of national wealth and quality of human (Mohamed El samanoudi 2001:149)
The success of any institution and viability of tourist service depends on the extent to which the objectives for which it was created, so I had theavailability estimate tool contribute to judging the effectiveness of leisure tourism and attainment of objectives, and determine if there is a difference between targets and results achieved (Ahmad Fadil, 2002): 67).

Recreational tourism therefore represents no aspect of social activity, but the cornerstone of the attractions (AedlIssa, KhalifaBahbahany, 2000): 49.

It must be distinct tourist facilities, and through continuous interaction with the various sectors of tourism and provide specialized skills that serve the facility in General, where the tourist facilities study and analysis of the quality system (TQM) to assess the possibility of suitable employment as a working system to activate and develop tourism output systems (Mac Donand\&Deness, 1996): 320.

This answers the questions search

\section{Conclusions:}

the level of awareness in recreational tourism sector of the Republic of Egypt Arabic average percentage ranging from $57.5 \%$ to $65 \%$ there is a rare of tourist recreation specialist within tourism professionals

Recommendations: the need for attention to tourism professionals for recreational awareness because of its positive impact to the development of tourism. Provide specialized cadres in leisure tourism for tourism within the Arabic Republic of Egypt attractions. Attention to the need for cooperation between the Arabic Republic of Egypt attractions and other institutions, including departments of recreation physical education colleges to provide suitable graduates for the labor market development of recreational tourism awareness through various media in tourism sector workers Arabic Republic of Egypt

\section{References:}

\section{Arabic References:}

1- Ahmed Alfadel 2002: How Satisfaction About Recreational Leisure Activities with Prince Salman Social Center, Scientific Production, Overall Physical Education Researches Magazine, Zagazig University,Faculty of Physical Education for Girls,2002,page 64.

2- Ehab Mohamed Othman Fakeery2010:Tourism ,Hotel Services Promoting , Development Capability in 
Khartoum State 2005-2008, Unpublished Master Thesis, Faculty of Arts Shendy University, page 15,27.

3- Sayed Abdelhamid 2003:Attracton Types in Some Investing recreational Institutions, Master Thesis ,Helwan University Faculty of Physical Education,Alharam.

4- Sabaah Mahmoud et al 2007: An Introducion inTourismGeography Bagdad,page 45.

5- AdlyEissa,Khaleifa Bahbahany2000:Sorarity Recreational Sports Centers Evaluation in KuwaitState , Scientific Production, The Scientific Magazine of Physical Education and Sports, Volume Nineteenth, Helwan University, Faculty of Physical Education for Men Alharam,July.

6- Arab Tourism Magazine 2010, Volume (375) Nissan,Lenaon,Page 34.

7- Mohamed Alsamanoudy 2001: Recreation and Leisure Time, Mansoura, AlfersanPublisher.Mansoura.

8- Mohamed Hassan Pazouka 2008:Public Relations and Tourism, Dar Alnahda for Publishing ,Page 6.

9- Mohamed Dalf Ahmed Aldailamy, Fawaz Ahmed AlmoussaDeveloment Geography, Dar Alforkan,FirstEddition, Syri,2009,page 224.
10- Mohamed Omar Abdulrasoul Abdulla2015: Develop a strategy for tourist recreation in light of quality standard Arabic Republic of Egypt, the scientific journal of the Faculty of physical Education for Men in Alexandria, Alexandria University, p 46

11- Mohamed Omar Abdulrasoul Abdulla 2008:Proposed plan for Recreational tourism of Fayoum, unpublished $\mathrm{PhD}$ thesis, Faculty of physical education for Girls in Alexandria, Alexandria University, Page152.

\section{Foreign References:-}

12- F Felkelitness - studios alsErlebniswelten . In : A. Hermanns\&

13- F.Riedmüller( Hrsg ) : Management - Handbuch sport - Marketing Munchen , s . 147 - 157, 2001.

14- Kaiser , S. Struktur und Entwicklungkommer-zieller sport an bieter an Beispiel der Stadtkolim .In :Hoych , H ., ( Hrsg. ) : Finanzierung der sport, Aachen, 2002 p29.

15- Mac Donand\&Deness - J. 1996 : Total Quality Management: Acase study of the cherry Hill public schools, cherry hill, New Jersey. EDD, Columbia university teachers college.p320

16- http://ibnsaba. jeeran. com/archive/2010/1/1009840. htm 